\title{
Minerals from the Kakanui Volcanic Breccia: A 2017 Look at Geological Reference Materials for EPMA
}

\author{
John Fournelle ${ }^{1}$ and James Scott ${ }^{2}$ \\ ${ }^{1 .}$ Cameron EPMA Laboratory, Department of Geoscience, University of Wisconsin, Madison, WI, USA \\ 2. Department of Geology, University of Otago, Dunedin, New Zealand
}

The microanalytical community owes a large debt to Gene Jarosewich and his co-workers (Joe Nelen, Julie Norberg) at the Department of Minerals Sciences at the Smithsonian Institution National Museum of Natural History for their work in developing 31 mineral and glass microbeam standards [1] in the 1968-78 period [2]. Gene was very clear about the limitations of the standards, that X-ray counts should be acquired from multiple grains, as the stated wet chemical compositions represented averages of a large number of small of grains: "a reasonably large number of counts on a reasonably large number of grains" needed to be acquired on these standards. Despite some shortcomings of some of these materials (e.g., tiny grains difficult to mount and polish), they have served the community well.

With the development of FE SEMs and SDD EDX (not available back $\sim 3$ decades ago), researchers at the Smithsonian have re-evaluated the original NMNH standards [3][4][5][6]. Additional evaluations have been made of differences between web-purchased material vs NMNH material of nominally the same material. Fournelle [7] found that, unlike the official NMNH 111312/44 San Carlos olivine, which is Fo90.1, "San Carlos olivine" available from gem dealers spans Fo89.2 to Fo91.4. Evaluating 23 of the 200-300 micron NMNH San Carlos grains (71 measurements), he found there was a bit wider range of heterogeneity compared with the original publication, making it incumbent not to just count on one grain but to average, optimally, 5-10 grains. With assistance of NMNH, he mounted multiple grains of the 4 NMNH pyroxene standards, and found a range of compositions present in each sample [8]. Thus, if one used only one grain for a standard, there could be a finite probability that the actual grain composition could differ from the published (bulk) wet chemical one (itself an average of $>100$ s of grains).

Well known to many are the NMNH "Kakanui" standards developed by Jarosewich and co-workers , from megacrysts in Oligocene tuff in the South Island of New Zealand (Figures 1,2,3), described by Mason [9], [10]. Further, in the late 1980s, researchers at Otago University similarly evaluated minerals from the Kakanui outcrop as EPMA standards [11] [12]. One obvious question occurs to someone who's experienced mounting and then polishing and repolishing tiny grains such as the Kakanui ones: if the source Kakanui reference material occurs as megacrysts, what about larger standards? What is the level of megacryst homogeneity? If there are inclusions, are they easily seen and avoided? Is there any way that instead of crushing into 200-400 micron fragments, $\geq 1-2 \mathrm{~mm}$ "blocks" could be harvested? Can they then be accurately chemically characterized in situ? Currently larger fragments of these megacrysts are being studied at UW (Figure 4), to evaluate the potential for larger size standards, observing that some do have small inclusions (easily identified and avoided). This may be an acceptable limitation, if they are otherwise homogeneous for the major elements for which they are intended, with the benefit of being easily mountable and polished. They would need, however, to be individually characterized using primary standards (such as a mount of 25-50 grains of a wet chemically analyzed NMNH standard), as each one might be slightly different. It is worth noting a recent paper by Pankhurst et al [13] describing the characterization of an olivine standard by mapping out the spatial compositional domains, allowing a 'not perfectly homogeneous' but large reference grain to be used for accurate EPMA. 
References:

[1] E Jarosewich, JA Nelen and JA Norberg, Geostandards Newsletter, 4(1) (1980), p. 43-47.

[2] E Jarosewich, Journal of Research of the National Institute of Standards and Technology, 107(6)

(2002), p. 681-685. (A history of the development of the Smithsonian microbeam stds)

[3] T.R. Rose, Microscopy and Microanalysis, 14(S2) (2008), p. 528-529.

[4] EP Vicenzi and TR Rose, Microscopy and Microanalysis, 14(S2) (2008), p. 522-523.

[5] TR Rose, SS Sorensen and JE Post, AGU Fall Meeting Abstracts, 1 (2009), p. 2008.

[6] TR Rose, Microscopy and Microanalysis, 17(S2) (2011), p. 846-847.

[7] J Fournelle, Microscopy and Microanalysis, 17(S2) (2011), p. 842-843.

[8] J Fournelle, AGU Fall Meeting Abstracts, 1 (2012), p. 2827.

[9] B Mason, New Zealand Journal of Geology and Geophysics, 9:4 (1966), p. 474-480.

[10] B Mason, Contributions to Mineralogy and Petrology, 19(4) (1968), p. 316-327.

[11] A Reay, RD Johnstone and Y Kawachi, Geostandards Newsletter, 13(1) (1989), p. 187-190.

[12] A Reay, RD Johnstone and Y Kawachi, Geostandards Newsletter, 17(1) (1993), p. 135-136.

[13] MJ Pankhurst, R Walshaw and D Morgan, Geostandards and Geoanalytical Research, 41 (2017), p. 85-91.

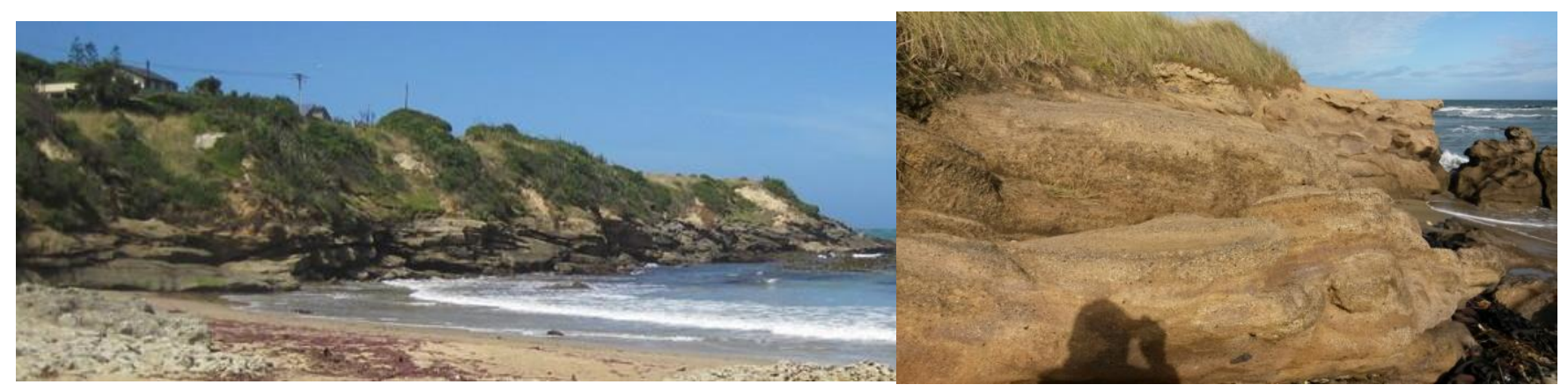

Figure 1. South Head, Kakanui. January 2017, tide coming in.

Figure 2. North Head, Kakanui, January 2017

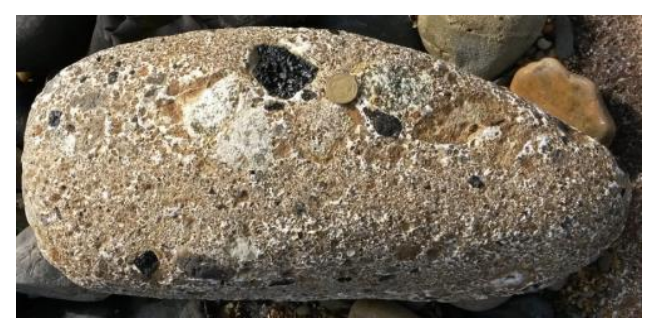

Figure 3. Block of breccia tuff from Kakanui, North Head ( 15 inches long)

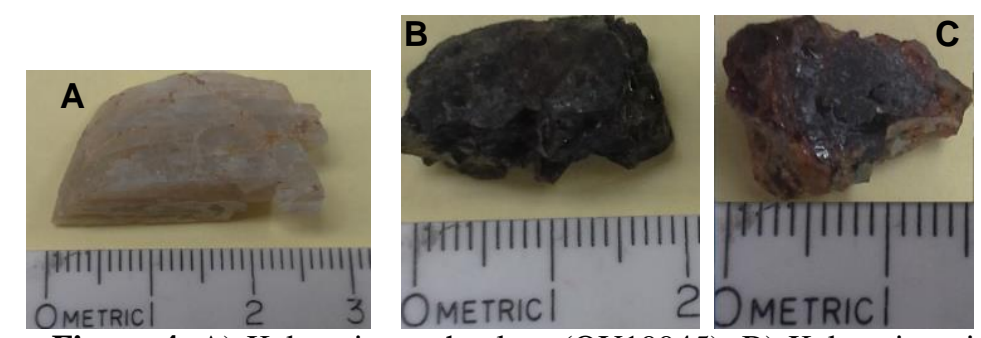

Figure 4. A) Kakanui anorthoclase (OU19945), B) Kakanui augite (OU25654), C) Kakanui pyrope (OU20249). Scale 1-3 centimeters. 